ARTICLE

\title{
Reproductive biology of king weakfish, Macrodon ancylodon (Perciformes, Sciaenidae) from the northeastern coast of Brazil
}

\author{
Biología reproductiva de la pescadilla real, Macrodon ancylodon (Perciformes, Sciaenidae), de la costa \\ noreste de Brasil
}

\section{Alana dos Santos Cardoso ${ }^{1 *}$, Nayara Barbosa Santos ${ }^{1}$, Zafira da Silva de Almeida ${ }^{1,2}$, Raimunda N. Fortes C. Neta ${ }^{2}$ and Lorrane Gabrielle Cantanhêde ${ }^{1}$}

\begin{abstract}
'Laboratory of Fisheries and Aquatic Ecology (Laboratório de Pesca e Ecologia Aquática-LabPEA), State University of Maranhão (UEMA), Cidade Universitária Paulo VI, S/N-Tirirical, Cidade Operária, CEP 65055-310, São Luís, MA, Brazil. *ealana@hotmail.com

${ }^{2}$ Department of Chemistry and Biology, State University of Maranhão (UEMA), Cidade Universitária Paulo VI, S/N-Tirirical, Cidade Operária, CEP 65055-310, São Luís, MA, Brazil
\end{abstract}

Resumen.- Se estudió la biología reproductiva de Macrodon ancylodon, pez de importancia comercial ampliamente distribuido a lo largo de la costa atlántica de América del Sur, a partir de 240 muestras colectadas en la costa de la provincia de Maranhão, noreste de Brasil. Los especímenes variaron de 18,2 cm a 33,5 cm, exhibiendo alometría positiva. La longitud total de la primera madurez sexual fue de 21,13 cm. M. ancylodon tiene una maduración gonadal asincrónica y sería un desovador parcial dentro de un período reproductivo. Tanto la longitud como el peso de las hembras no afectaron la fecundidad relativa. El análisis del índice gonadosomático, factor de condición y frecuencia de los estadios de maduración muestra que $M$. ancylodon es capaz de reproducirse durante todo el año, a pesar de que se observaron picos de desove durante noviembre-diciembre y agosto-septiembre. Los resultados evidencian que el área de estudio es utilizada por $M$. ancylodon para la reproducción. Los datos obtenidos serán de gran valor para el desarrollo de estrategias de gestión de los recursos pesqueros.

Palabras clave: Reproducción, peces estuarinos, gónadas, índice gonadosomático, desove, factor de condición

\begin{abstract}
The reproductive biology of Macrodon ancylodon, a commercially important fish widely distributed along South America's Atlantic coast, is described from 240 specimens collected in northeastern Brazil. Specimens ranged from 18.2 to $33.5 \mathrm{~cm}$ in length, exhibiting positive allometry. Total length at first sexual maturity was $21.13 \mathrm{~cm}$. M. ancylodon has an asynchronous gonadal maturation and would be a batch spawner within a reproductive period. Total weight and length of females do not affect the relative fecundity values in this species. Analysis of the gonadosomatic index, condition factor and frequency of maturational stages shows that $M$. ancylodon was capable of reproducing throughout the year, despite the fact that spawning peaks were observed during November-December and August-September. The results are evidence that the study area is used by $M$. ancylodon for reproduction. The data will also be important for the development of stock management strategies.
\end{abstract}

Key words: Reproduction, estuarine fish, gonad, gonadosomatic index, spawning, condition factor

\section{INTRODUCTION}

Macrodon ancylodon (Bloch \& Schneider, 1801), popularly known as king weakfish, belongs to the family Sciaenidae. It is a valuable commercial fish species in Brazil (Haimovici et al. 1996, Isaac \&Braga 1999), particularly the northeastern state of Maranhão (Serpa 2004, Mourão et al. 2009) where it ranks third in commercial importance, with landings of 2,724.9 $\mathrm{t}$ or $6.9 \%$ of total fish caught in the state (Almeida et al. 2000, IBAMA 2008, Almeida et al. 2009).
The distribution of M. ancylodon is restricted to the western part of the Atlantic Ocean, from Venezuela to Argentina (Cervigón 1993, Carvalho-Filho 1999). It is a demersal species found in estuarine and marine habitats of tropical and subtropical regions at depths of up to 60 $\mathrm{m}$ (Camargo \& Isaac 2005, Castro et al. 2015). It is characterized by an elongated, yellowish/grayish body, up to $45 \mathrm{~cm}$ in length, moderately compressed with arched dorsal and ventral fins (Santos et al. 2006). The head is 
pointed and compressed; the mouth is large, oblique and terminal (Alfaro et al. 2012). The jaw projects in front of the maxillary, and the teeth are rounded with large caninelike teeth that are exposed even when the mouth is closed (Cervigón 1993).

Data relating to the reproductive characteristics of this economically important species are important for understanding its behavior, assessing fish stocks and developing suitable management strategies (Santos et al. 2003). In the specific case of $M$. ancylodon populations in the coast state of Maranhão, data are urgently required as the fishing fleet is expanding but management policies are still being formulated. If the fishery is not managed coherently with the introduction of a closed season and increased protection of breeding grounds, exploitation will soon exceed the carrying capacity of the fish community. Thus, this study investigated the reproductive biology of $M$. ancylodon in the municipality of Raposa (a major fishing community of the state of Maranhão) via macroscopic/microscopic descriptions of the maturational stages, determination of the total weight/overall length relationship, sex ratio, size at first sexual maturity, fecundity, and spawning activity.

\section{Materials AND MEthodS}

\section{SAMPLING AREA}

Fish were collected in the Maranhense Gulf region, near the city of Raposa, encompassing the bays of São Marcos and São José. The region is part of the metropolitan area of São Luís city and is washed by the Atlantic Ocean. The municipality of Raposa is located northwest of São Luís (or Upaon Açú) Island, $30 \mathrm{~km}$ from the regional capital, between coordinates $2^{\circ} 25^{\prime} 22^{\prime \prime} \mathrm{S}$ and $44^{\circ} 5^{\prime} 21^{\prime \prime W}$ (Fig. 1).

\section{SAMPLE COLLECTION}

Samples of $M$. ancylodon were obtained between December 2012 and November 2013 from fish markets in Raposa. Bimonthly, one $16.5 \mathrm{~kg}$ box of fish of each available market grade (medium or large) was purchased and processed for general biological data. An average of 40 specimens were collected in each survey period and all samples, which were previously identified and weighed, were analyzed in the Fisheries Laboratory of Aquatic Ecology, State University of Maranhão (UEMA). Total length (TL) and standard length (SL) in centimeters $(\mathrm{cm})$ were recorded, along with total weight (TW) and gutted weight (EW) in grams (g).

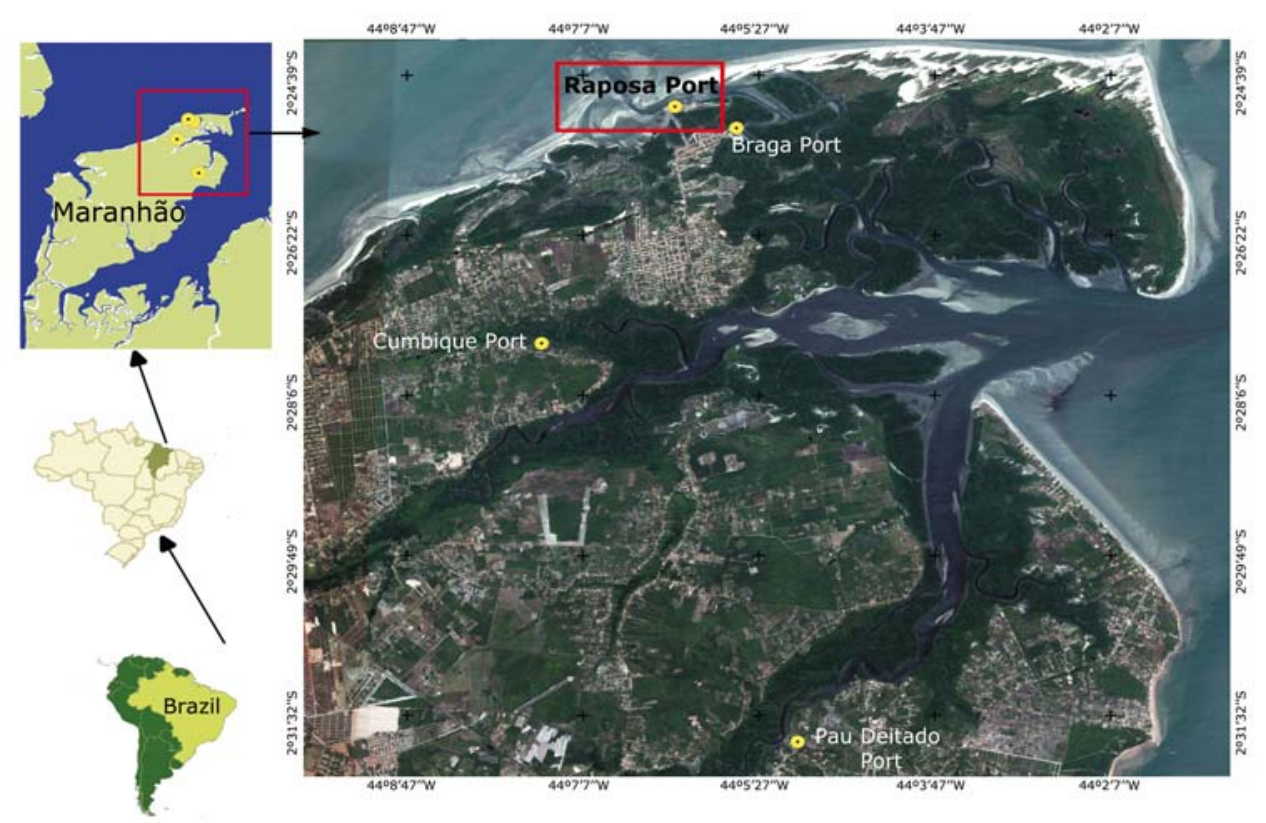

Figure 1. Sampling area in the Maranhense Gulf, highlighting the fishing community of Raposa, Maranhão State, Brazil / Área de muestreo en el Golfo Maranhense, destacando la comunidad pesquera de Raposa, Maranhão, Brasil 


\section{LABORATORY PROCEDURES}

For each specimen, a ventral longitudinal section was performed to extract the gonads for macroscopic examination. The following characteristics were noted: color, vascular volume in relation to the abdominal cavity, blood flow, visibility of oocytes plus presence of sperm and consistency.

The sex and maturity stage of each individual were identified macroscopically and microscopically. A previously established maturity scale was used for the macroscopic classification of gonads, adapted by BrownPeterson et al. (2011), as follows: A) Immature (never spawned); B) Developing (ovaries beginning to develop, but not ready to spawn); C) Spawning capable (fish are developmentally and physiologically able to spawn in this cycle); D) Regressing (cessation of spawning); E) Regenerating (sexually mature, reproductively inactive). The gonads were weighed (WG) on a precision scale and the weight was expressed in grams $(\mathrm{g})$.

For microscopic analysis, the gonads were dissected into three segments (proximal, medial and distal), and the medial portion fixed in a $10 \%$ formaldehyde solution for $24 \mathrm{~h}$. After fixation, the gonads were dehydrated in an ascending alcohol series, cleared in xylene, embedded in paraffin wax for the preparation of $\sim 5-\mu \mathrm{m}$-thick sections and stained with hematoxylin-eosin (HE). Histologically, female maturational stages were identified via characterization of the various oocyte types, following the scale of Brown-Peterson et al. (2011).

For analysis of fecundity a volumetric method, described in Vazzoler (1996) was adapted. A small portion (approximately $5 \mathrm{~g}$ ) of a fresh ovarian tissue of 80 'spawning capable' females were used. In brief, the oocyte mass was diluted in a known volume (s) of 70\% alcohol, the flask was stirred and a 1-ml aliquot was removed with a Stempel pipette. The aliquot was placed on a processed Dollfus plate and the total number of oocytes counted (n) under a stereomicroscope with an $8 \mathrm{x}$ objective and 10x ocular lens. The diameter of the oocytes was measured with a stereomicroscope and their frequency distribution was used to estimate the type of spawn. The mean diameter of mature oocytes was estimated from the arithmetic mean of the size of all mature oocytes.

\section{STATISTICAL ANALYSIS}

The relationship between total length and total weight was established by nonlinear regression. The adjustment of the curve, represented by the mathematical expression $\mathrm{TW}=a \times \mathrm{TL}^{b}$, and adjusted by the least-squares method was obtained by the least-squares method, with a confidence level of $\pm 95 \%(P<0.05)$ where $a$ and $b$ are parameters of the equation (Snedecor \& Cochram 1980, Sokal \& Rohlf 1987); where $\mathrm{TW}=$ total weight and $\mathrm{TL}=$ total length. Coefficient $b$ was compared between males and females by the Student's t test (Zar 1996).

The sex ratio was obtained for the entire experimental period, for 2 months (Bimonthly) and overall length classes (Vazzoler 1996). To check possible differences in these values, a $\chi^{2}$ test was used with a significance level of $P=0.05$.

To analyze the size at first maturation $\left(L_{50}\right)$, the maturation stages were grouped as immature (stage A) or mature (stages B, C, D and E), according to BrownPeterson et al (2011).The percentage mature by length was calculated and considered a dependent variable $(y)$; total length was considered an independent variable $(x)$. These values were subsequently adjusted to a logistic curve using the STATISTICA 6.0 program, according to the formula: $P=1 /\left(1+\exp ^{[-r(L-L 50)]}\right)$.

The reproductive period and spawning season were determined by analyzing the bimonthly frequency of the developmental stages, the variation in mean values of the gonadosomatic index $(\Delta \mathrm{RGS})$ and condition factor $(\Delta \mathrm{K})$. The periodicity of the reproductive process for this species was determined by analyzing the bimonthly frequency of the developmental stages.

The gonadosomatic index (RGS) was calculated for mature stages B, C and D from gonad mass as a percentage of the total body weight to indicate the annual variations in gonadal development.

The condition factor $(\mathrm{K})$ was considered as a quantitative indicator of health status (healthiness) or welfare of fish, reflecting recent food conditions (Le Cren 1951). This factor was determined from the relationship between individual weight and length, and may be expressed by isometric or allometric factors. Two models were considered in estimating allometric $\mathrm{K}$ values: $\mathrm{K}=$ $\mathrm{TW} / \mathrm{TL} b$ (total condition factor) and $\mathrm{K}^{*}=\mathrm{GW} / \mathrm{TL} b$ (somatic condition factor); where $\mathrm{TW}=$ total weight, $\mathrm{TL}=$ total length and $\mathrm{GW}=$ gonad weight. Differences in the distribution of bimonthly values for $\Delta \mathrm{RGS}$ and $\Delta \mathrm{K}$ were tested using the nonparametric Kruskal-Wallis method (Kruskal \& Wallis 1952). All tests were performed using STATISTICA 6.0 software (StatSoft Inc.). 
Absolute fecundity was defined as the number of mature oocytes that can be expulsed in the reproductive period and estimated by $N=(n \cdot V) / v$, where $N$ is the total number of oocytes; $n$ is the mean number of yolked oocytes obtained in the sub-samples ( 3 replicates); $V$ is the total volume of the solution $(300 \mathrm{ml})$ and $v$ the volume of the subsample $(5 \mathrm{ml})$. Relative fecundity was established from the relationship between the number of oocytes per gram of total body weight (TW) and total length (TL).

For analysis of variance (ANOVA), normality and homogeneity were tested via Tukey and Fligner-Killeen tests, respectively. Statistical tests were performed in ' $R$ Program' (R Development Core Team 2011).

\section{Results}

The total length of Macrodon ancylodon specimens ranged from $18.2 \mathrm{~cm}$ to $33.5 \mathrm{~cm}$, while the minimum and maximum individual weights observed were 40.7-370 g, respectively. The weight and length of females versus males were not significantly different $(P<0.05)$ (Table 1$)$. Negative allometry was recorded for females and positive allometry for males (Fig. 2). The regression coefficient (b) showed no significant difference for males and females $(t=1.36 ; P>0.05)$.

The sex ratio for the entire sampling period was 2.72 females per one male. Females were dominant at all sampling times, except for the period April/May when a greater number of males were recorded (Table 2). The $\chi^{2}$ test value of 48.56 indicated no significant difference for all bimonthly periods, except April-May.

Considering the sex ratio by length class in $M$. ancylodon, most females were between 26 and $28 \mathrm{~cm}$ in length. Significant differences were observed between

Table 1. Parameters for the length-weight relationship of male and female Macrodon ancylodon collected in the municipality of Raposa, Maranhão State, Brazil / Los parámetros para la relación longitud-peso de machos y hembras de Macrodon ancylodon recolectados en el municipio de Raposa, Maranhão, Brasil

\begin{tabular}{ccccccc}
\hline & $N$ & TL (Min-Max) & $A$ & $B$ & $R^{2}$ & Equation \\
\hline Female & 166 & $20-33.5$ & 0.0092 & 2.98 & 0.85 & $y=0.0092 x^{2.9872}$ \\
Male & 61 & $18.2-32$ & 0.0026 & 3.37 & 0.92 & $y=0.0026 x^{3.3725}$ \\
\hline
\end{tabular}

a)

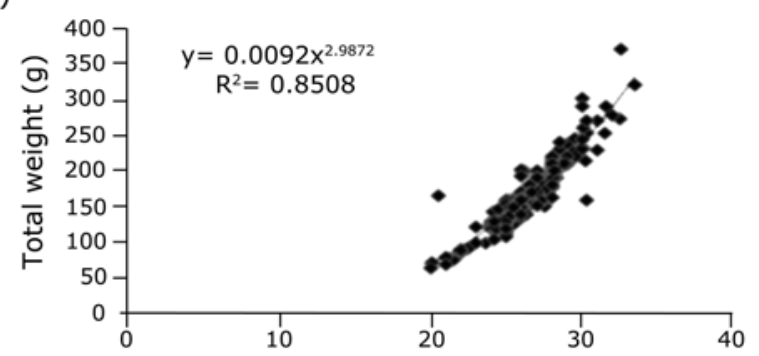

b)

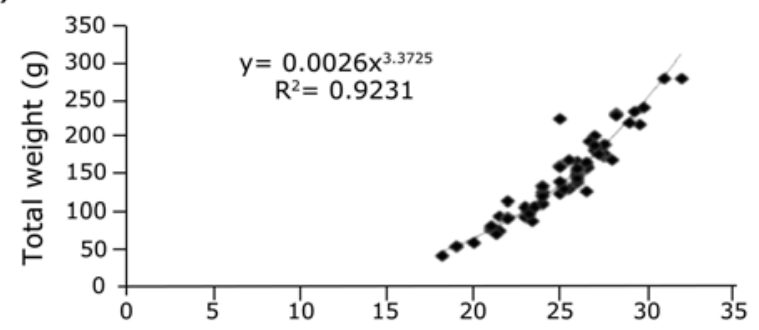

c)

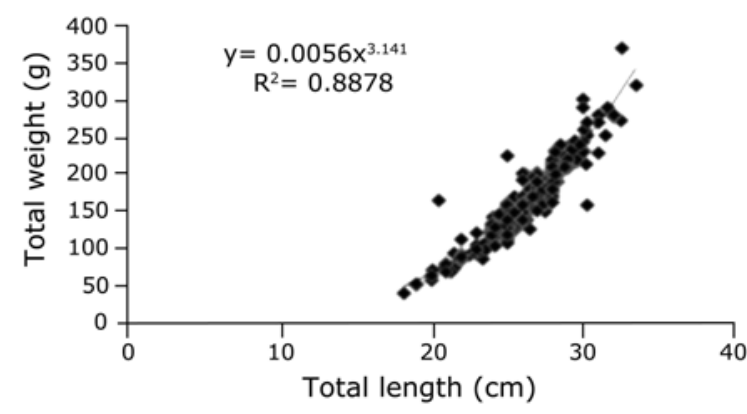

Figure 2. Graphical representation of the relationship between the total weight (TW) and total length (TL) of a) females, b) males and c) combined sexes for Macrodon ancylodon collected in the municipality of Raposa, Maranhão State, Brazil, between November 2012 and December 2013 / Representación gráfica de la relación entre el peso total (TW) y la longitud total (TL) a) de las hembras, b) machos y c) sexos combinados para Macrodon ancylodon recolectados en el municipio de Raposa, Maranhão, Brasil, entre noviembre 2012 y diciembre 2013

Table 2. Bimonthly sex ratio of Macrodon ancylodon specimens collected in the municipality of Raposa, Maranhão State, Brazil, between November 2012 and December 2013 / Proporción bimestral de sexos del Macrodon ancylodon recogidos en el municipio de Raposa, Maranhão, Brasil, entre noviembre 2012 y diciembre 2013

\begin{tabular}{lccccc}
\hline $\begin{array}{c}\text { Sampling } \\
\text { period }\end{array}$ & $\begin{array}{c}\text { Female } \\
(n)\end{array}$ & $\begin{array}{c}\text { Male } \\
(n)\end{array}$ & $\begin{array}{c}\text { Total } \\
(n)\end{array}$ & Fe & $\chi^{2}$ \\
\hline Nov/Dec & 36 & 5 & 41 & 20.5 & 23.43 \\
Feb/Mar & 29 & 9 & 38 & 19 & 10.52 \\
Apr/May & 11 & 21 & 32 & 16 & 3.125 \\
Jun/Jul & 27 & 9 & 36 & 18 & 9 \\
Aug/Sep & 30 & 10 & 40 & 20 & 10 \\
Oct/Dec & 33 & 7 & 40 & 20 & 16.9 \\
\hline
\end{tabular}


the sexes for the length classes 24-26, 26-28, 28-30 and $30-32 \mathrm{~cm}$, with the highest percentage in the length class $26-28 \mathrm{~cm}$, which was statistically significant (Table 3 ). The size at first sexual maturity in $M$. ancylodon for the study period was $20.30 \mathrm{~cm}$ for males, $22.14 \mathrm{~cm}$ for females and $21.13 \mathrm{~cm}$ for the combined sexes (Fig. 3).

The average values of $\Delta \mathrm{RGS}$ and $\Delta \mathrm{K}$ for $M$. ancylodon were not significantly different between bimonthly sampling periods (Kruskal-Wallis test, $P>0.05$ ) (Fig. 4). Mature individuals for both sexes were observed throughout the year (Fig. 3); however, 2 reproductive activity peaks were observed in the period NovemberDecember and August-September. This pattern was confirmed by microscopic analysis, which registered the occurrence of oocytes at various stages of development (Fig. 5).

The volume, color, thickness and blood supply to the ovaries of analyzed specimens varied according to the maturation stage, with tones ranging from light-rose color

Table 3. $\chi^{2}$ values for length classes $(\mathrm{cm})$ in Macrodon ancylodon collected in the municipality of Raposa, Maranhão State, Brazil, between November 2012 and December 2013 / Valores del $\chi^{2}$ para las clases de talla $(\mathrm{cm})$ de Macrodon ancylodon recogidos en el municipio de Raposa, Maranhão, Brasil, entre noviembre 2012 y diciembre 2013

\begin{tabular}{cccc}
\hline $\begin{array}{c}\text { Length } \\
\text { class } \\
(\mathrm{cm})\end{array}$ & $\begin{array}{c}\text { Male } \\
(n)\end{array}$ & $\begin{array}{c}\text { Female } \\
(n)\end{array}$ & $\chi^{2}$ \\
\hline $18-20$ & 3 & 0 & 3 \\
$20-22$ & 7 & 6 & 0.076923 \\
$22-24$ & 8 & 8 & 0 \\
$24-26$ & 14 & 32 & $7.043478^{*}$ \\
$26-28$ & 20 & 63 & $22.27711^{*}$ \\
$28-30$ & 7 & 39 & $22.26087^{*}$ \\
$30-32$ & 1 & 14 & $11.26667^{*}$ \\
$32-34$ & 1 & 4 & 1.8 \\
Total & 61 & 166 & $48.56828^{*}$ \\
\hline
\end{tabular}

*Significant at $P<0.05$
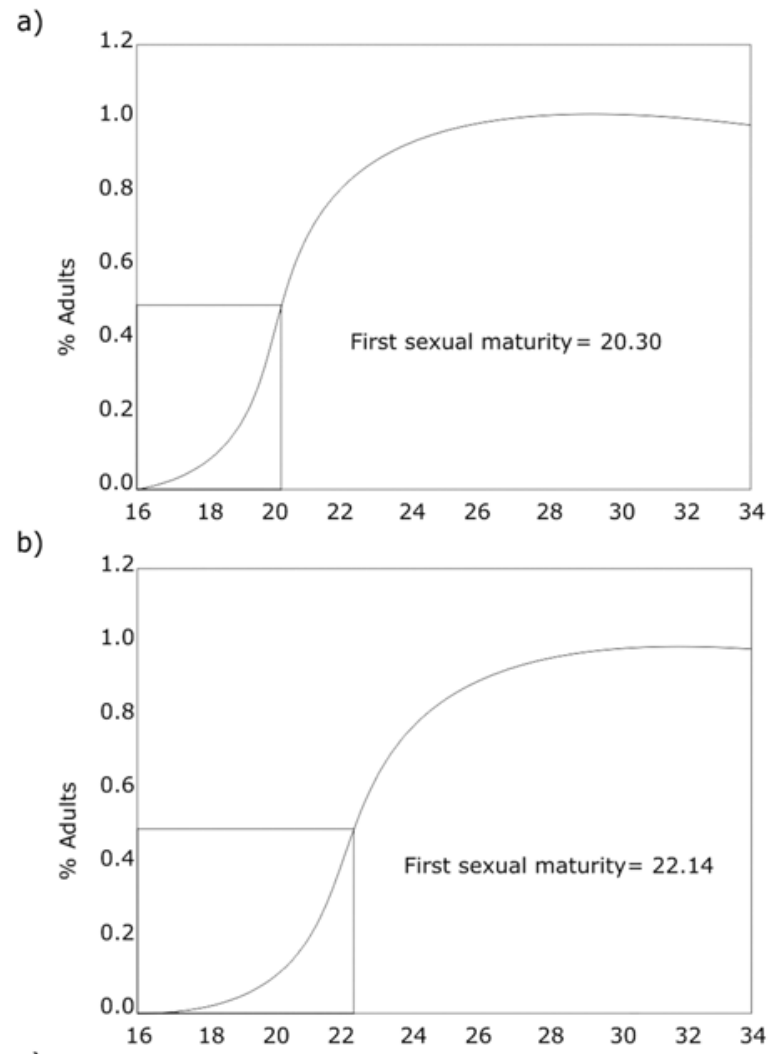

c)

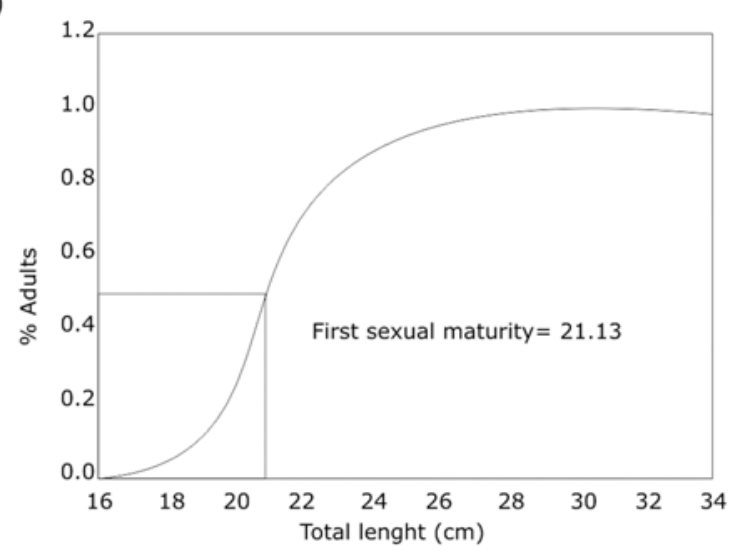

Figure 3. Length at first maturity for a) males, b) females and c) combined sexes of Macrodon ancylodon collected in the municipality of Raposa, Maranhão State, Brazil, between November 2012 and December 2013 / La talla de primera madurez para a) machos, b) hembras y c) sexos combinados de Macrodon ancylodon recolectados en el municipio de Raposa, Maranhão, Brasil, entre noviembre 2012 y diciembre 2013 


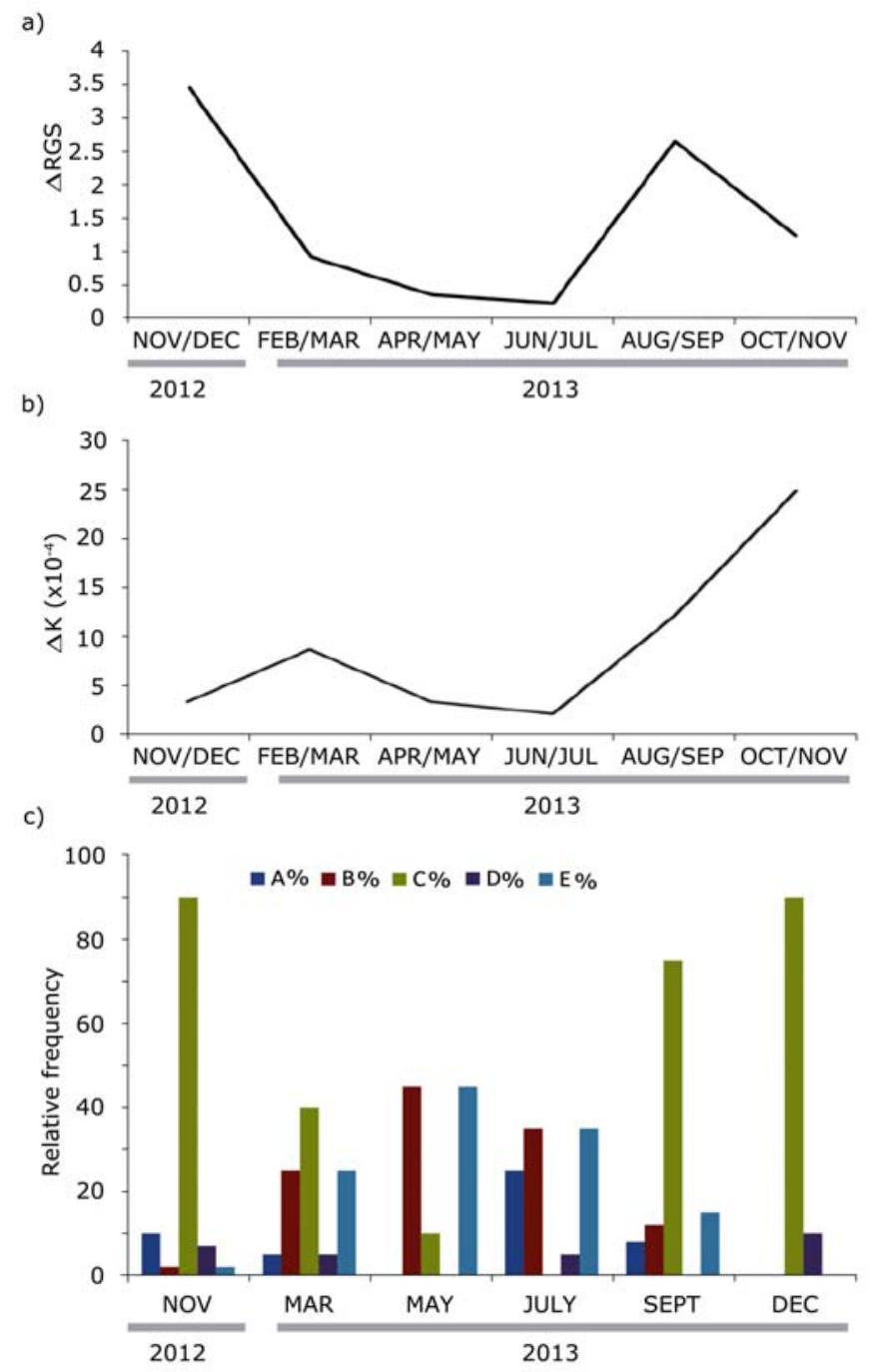

Figure 4. Average values for a) $\Delta R G S, b) \Delta K$ and c) the bimonthly relative frequency of maturational stages for Macrodon ancylodon females collected in the municipality of Raposa, Maranhão State, Brazil, between November 2012 and December 2013. A= immature; B= developing; C= spawning capable; $D=$ regressing (cessation of spawning); $E=$ regenerating / Los valores medios de a) $\Delta R G S, b$ ) $\Delta K$ y c) la frecuencia relativa bimestral de estadios de maduración para las hembras de Macrodon ancylodon recolectados en el municipio de Raposa, Maranhão, Brasil, entre noviembre 2012 y diciembre 2013 A= inmadura; B= desarrollo; C= capaz de desovar; D= regresión (cese del desove); E= regeneración

(resting period) to bright yellow (final maturity), due to the color of the yolk-filled oocytes. Macroscopic evaluation of ovaries allowed the categorization, in $M$. ancylodon, of 5 maturational stages: immature, developing, spawning capable, regressing and regenerating (Fig. 5).

The correlation between phases for gonad development in females was identified through characterization of cells in the predominant oocyte types (Table 4).
Mean absolute fecundity, defined as the number of oocytes that could potentially be eliminated in the next spawning (yolked oocytes), ranged from 27,310 to 246,287 oocytes. This variation resulted from differences in the total weight and total length between individual fish. Mean absolute fecundity was 116,129 oocytes per spawning, while the average relative fecundity in $M$. ancylodon was estimated at 4004 oocytes per $\mathrm{cm}$ total length and 531 oocytes per gram total weight. Diameter measurements of vitellogenic oocytes showed that there 


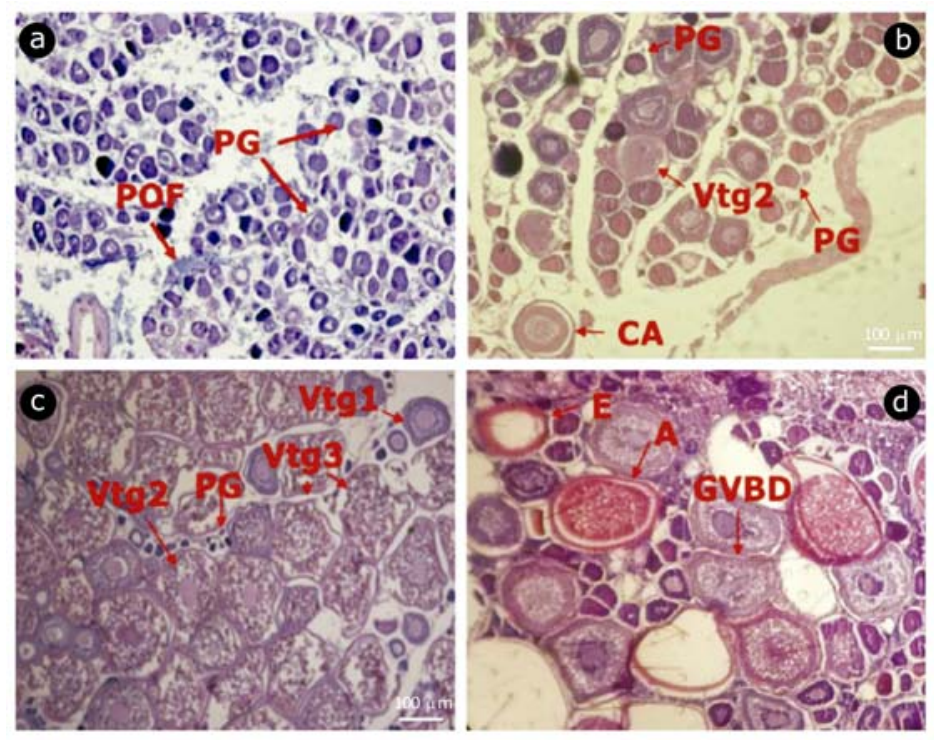

Figure 5. Photomicrograph of Macrodon ancylodon ovaries during the gonadal cycle. a) Regenerating reproductive phase; b) Developing reproductive phase; c) Spawning capable reproductive phase; d) Regressing phase. HE staining at 100x. PG= primary growth oocyte; POF= postovulatory follicle complex, $\mathrm{Vtg} 2=$ secondary vitellogenic oocytes; $\mathrm{Vtg} 3=$ tertiary vitellogenic oocyte; $\mathrm{CA}=$ cortical alveolar oocytes; $\mathrm{A}=$ atretic oocyte; GVBD= residual oocyte undergoing germinal vesicle breakdown; E= empty / Microfotografía de ovaries del Macrodon ancylodon durante el ciclo gonadal. a) Fase reproductiva en regeneración; b) Fase de desarrollo; c) Fase reproductiva capaz de desove; d) Fase de regresión. Tinción con $\mathrm{HE}$ en 100x. PG= ovocito de crecimiento primario, POF= complejo de folículos postovulatorios, Vtg2= ovocitos vitelogénicos secundarios, $\mathrm{Vtg} 3=$ ovocito vitelogénico terciario, $C A=$ ovocitos corticales alveolares, $A=$ ovocito atrésico, $G V B D=$ ovocito residual sometido a ruptura de vesícula germinal, $\mathrm{E}=$ vacío

Table 4. Features of maturity stages of Macrodon ancylodon females collected in the municipality of Raposa, Maranhão State, Brazil, between November 2012 and December 2013 / Características de las etapas de maduración de hembras de Macrodon ancylodon recogidos en el municipio de Raposa, Maranhão, Brasil, entre noviembre 2012 y diciembre 2013

\begin{tabular}{|c|c|c|c|c|c|}
\hline \multirow{2}{*}{ Features } & \multicolumn{5}{|c|}{ Classification } \\
\hline & Immature & Developing & $\begin{array}{c}\text { Spawning } \\
\text { capable }\end{array}$ & Regressing & Regenerating \\
\hline Size in relation to abdominal cavity & $<1 / 4$ & $1 / 2-1 / 3$ & $3 / 4-4 / 4$ & $1 / 3-1 / 2$ & $1 / 2-1 / 3$ \\
\hline Presence of oocytes & No & Yes & Yes & Few & Few \\
\hline Color/features of oocytes & - & $\begin{array}{l}\text { Small+large, } \\
\text { whitish color }\end{array}$ & Yellow/large & - & - \\
\hline Vascularization & No & $\begin{array}{l}\text { Greater than in } \\
\text { the previous stage }\end{array}$ & Elevated & Hemorrhagic & $\begin{array}{l}\text { Enlarged } \\
\text { blood vessels }\end{array}$ \\
\hline Color of gonads & Translucent & Light pink & Yellow & Red & Orange \\
\hline Predominant oocyte type & $\begin{array}{l}\text { Primary } \\
\text { growth oocyte }\end{array}$ & $\begin{array}{l}\text { Cortical alveolar } \\
\text { oocytes, } \\
\text { secondary } \\
\text { vitellogenic } \\
\text { oocytes }\end{array}$ & $\begin{array}{l}\text { Tertiary } \\
\text { vitellogenic } \\
\text { oocyte }\end{array}$ & $\begin{array}{l}\text { Atretic } \\
\text { oocyte, some } \\
\text { cortical } \\
\text { alveolar } \\
\text { oocytes }\end{array}$ & $\begin{array}{l}\text { Primary } \\
\text { growth } \\
\text { oocyte, } \\
\text { degenerating } \\
\text { postovulatory } \\
\text { follicle } \\
\text { complex }\end{array}$ \\
\hline
\end{tabular}




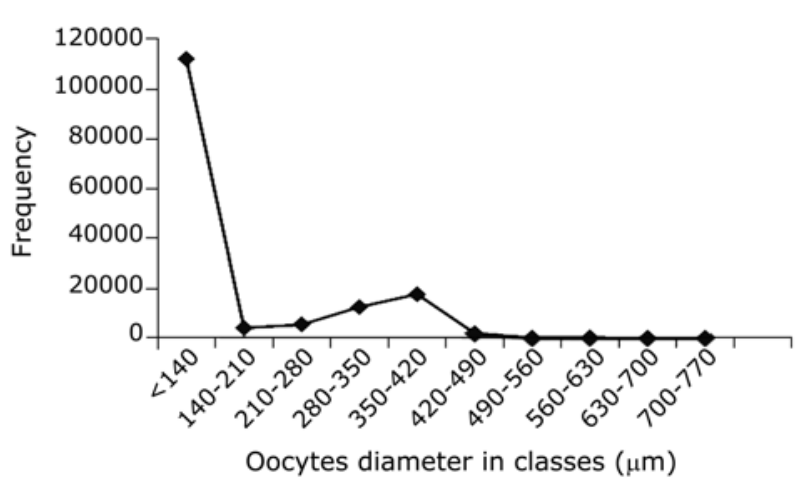

Figure 6. Distribution of the oocyte diameter frequency of gonads of Macrodon ancylodon at the final stage of maturation / Distribución de la frecuencia del diámetro de ovocito en las gónadas de Macrodon ancylodon durante la fase final de maduración

are several size classes in a gonad (Fig. 6). Histological analyses carried out to establish whether the different diameters corresponded to different stages of oocyte development found that oocytes ranged from 140-770 $\mu \mathrm{m}$ in diameter, confirming that spawning in M. ancylodon is asynchronous and sporadic.

\section{Discussion}

Data from the weight-length relationship for M. ancylodon analyzed in this study showed negative allometry for females and positive allometry for males, a totally different result to that reported by Camargo-Zorro (1999) from the Caeté River estuary. It was also confirmed that weightlength relationships were allometrically positive for specimens collected on the Pará coast (Ikeda 2003) and from São Marcos Bay (Santos 2007). In accordance with Ricker (1975), the cause of these variations may be differences among populations of the same species or the same population in different years, and is presumably associated with their nutritional conditions. The value from $t$-tests calculated in this study indicated that there was no significant difference between the sexes, (i.e., they can be analyzed in an aggregated manner). In studies performed with individuals from the Pará coast (Ikeda 2003), $t$-tests indicated significant differences between the sexes. Santos (2007) noted that in M. ancylodon, as in most teleosts, males reached maturity at a lower total length than females. Ikeda (2003) reports that, at shorter total lengths, males were predominant, unlike females, which were larger. Females may have a greater life expectancy than males or a higher growth rate. In our study, the sex ratio favored females by 2.72 to 1 , which differed from the results of Santos (2007), who recorded a $3: 1$ female/male ratio. However, sex ratio could change by spatial segregation during spawning activity, or for sampling biases. Meanwhile, data from the REVIZEE (Program to Evaluate the Sustainable Potential of Living Resources in the Exclusive Economic Zone) noted a 2:1 female/male sex ratio (Ikeda et al. 2003), which differed from the findings of Ikeda (2003) on the Pará coast of a 1:1 male/female ratio.

From histological analysis performed in this study, $M$. ancylodon was found to be a batch spawner, with spawning occurring mainly during November/December and August/September (dry season). Yamaguti (1967), Ikeda (2003) and Santos (2007) stated that this species is characterized by fractional spawning, but is able to reproduce throughout the year. Previously it was reported that this species is a batch spawner in Brazil (Vazzoler 1963, Isaac-Nahum \& Vazzoler 1983) and in the Rio de la Plata region (Vizziano \& Berois 1990 and Militelli \& Macchi 2004). Ikeda (2003) noted that the peaks of spawning were closely linked to rainfall. Multiple spawning is typical in species of tropical, temperate and subtropical waters, which is thought to improve survival (Nikolsky 1963).

The size of M. ancylodon at which $50 \%$ of the population reached sexual maturity in this study was 21.13 $\mathrm{cm}$ total length for both sexes. Similar results were obtained by Camargo-Zorro (1999) in specimens from the Caeté River (21.5 cm), by Santos (2007) in São Marcos Bay $(21.05 \mathrm{~cm})$, and by Santana $(1998)$ in fish $(18.6 \mathrm{~cm})$ from the coastal region of Salinas (Pará) on the northern coast of Brazil. Our estimates of L50 were considerably lower than those estimates for individuals of the same species from the Pará coastal area $(25.08 \mathrm{~cm})$ (Ikeda 2003). A comparison of these results with those of two populations from the south coast of Brazil (Vazzoler 1963, Yamaguti 1967) would seem to indicate that individuals from habitats at lower latitudes reach sexual maturity at lower average lengths. On the other hand, Militelli et al. (2013) found values of L50 for M. ancylodon (in the Río de La Plata and Buenos Aires Coastal Zone, Argentina) approximated to those recorded in our study (male $=19.27$ $\mathrm{cm}$; female $=23.07 \mathrm{~cm}$; both sex combined $=21.1 \mathrm{~cm}$ ). Santos et al. (2006) studying population genetic structuring of the Macrodon ancylodon in Atlantic coastal waters of South America, explains that populations of the North Brazil and the Brazil currents, with warmer waters, form a clade (tropical clade) separated by 23 fixed mutations from the populations that inhabit regions of colder waters 
influenced by the Brazil and Malvinas currents (subtropical clade).

In this study, the absolute fecundity in M. ancylodon ranged from 27,310 to 246,287 oocytes. Vazzoler (1963) found a fecundity of $M$. ancylodon in southeastern Brazil (Santos - São Paulo) ranging from 26,210 to 178,114 . On the other hand Militelli et al. (2013) found batch fecundity values of 12,400 to 225,700 for M. ancylodon in the Río de la Plata and Buenos Aires Coastal Zone, Argentina. High fecundity is a characteristic of fish species with free eggs and an absence of parental care (Lowe-McConnell 1987). There can be interspecific and intraspecific variations in fertility. For example, within the Sciaenid family, many marine species behave as what is known as r-strategists, i.e., they produce many offspring, whereas freshwater species tend to be k-strategists, i.e., they produce few offspring (Militelli \& Macchi 2004, Juras \& Yamaguti 1985, 1989; Militelli et al. 2013). In tropical waters, where temperature is not limited, spawning is mainly influenced by environmental factors related to food supply (LoweMcConnell 1987).

From the results of this study, it was concluded that M. ancylodon is a batch spawner. Analysis of the gonadosomatic index, condition factor and frequency of maturational stages indicated that this species is capable of reproducing throughout the year. The frequency of mature and spawned individuals in all maturity stages showed that $M$. ancylodon reproduced in the estuary near the city of Raposa (São Marcos Bay and part of São José Bay). The results of this study provide important data for the development of protective and management strategies of $M$. ancylodon stocks.

\section{ACKNOWLedgMenTs}

We thank the Maranhão State Research Foundation (Fundação de Amparo à Pesquisa e ao Desenvolvimento Científico e Tecnológico do Maranhão: FAPEMA) for financial support.

\section{LITERATURE CITED}

Alfaro AT, CS Costa, GG Fonseca \& C Prentice. 2010. Effect of extraction parameters on the properties of gelatin from King weakfish (Macrodon ancylodon) bones. Food Science and Technology International 15(6): 553-562.

Almeida ZS, AC Castro, AC Paz, N Barbosa, D Ribeiro \& T Ramos. 2000. Diagnóstico da pesca artesanal no litoral do Maranhão. Relatório Técnico. RECOS-MGP-MA, 63 pp. Projeto RECOS, São Luís.
Almeida ZS, AN Cavalcante, NB Santos \& VJI Nahum. 2009. Contribuição para gestão do Sistema de Produção Pesqueira pescada-amarela, Cynoscion acoupa (Pisces: Sciaenidae)(Lacepéde, 1802) na costa do Maranhão, Brasil. Boletim do Laboratório de Hidrobiologia 22: 10-23.

Brown-Peterson NJ, DM Wyanski, F Saborido-Rey, BJ Macewicz \& SK Lowerre-Barbieri. 2011. A standardized terminology for describing reproductive development in fishes. Marine and Coastal Fisheries 3: 52-70.

Camargo M \&V Isaac. 2005. Reproductive biology and spatiotemporal distribution of Stellifer rastrifer, Stellifer naso and Macrodon ancylodon (Sciaenidae) in the Caeté Estuary, Northern Brazil. Brazilian Journal of Oceanography 53: 13-21.

Camargo-Zorro MC. 1999. Biologia e estrutura populacional das espécies da família Sciaenidae (Pisces: Perciformes), no estuário do rio Caeté município de Bragança, Pará - Brasil. Dissertação de Mestrado, Universidade Federal de Pará, Bragança, 87 pp. <http://bdtd.ibict.br/vufind/Record/ UFPA_67c8088c4c8dbc98fc0adb33ec11075a>

Carvalho-Filho A. 1999. Peixes da costa brasileira, 320 pp. Editora Melro, São Paulo.

Castro DN, WMG de Lima, NCB Mendes, do Nascimento MS, ÍA de Freitas Lutz, CDNA Cardoso \& BB da Silva. 2015. Dieta natural de Macrodon ancylodon (Bloch\& Schneider, 1801) capturada por embarcações pesqueiras industria issedia das no Estado do Pará. Biota Amazônia. Biota Amazonia 5(3): 50-54.

Cervigón F. 1993. Los peces marinos de Venezuela, 498 pp. Fundación Científica Los Roques, Caracas.

Giarrizzo T, AJ Silva de Jesus, EC Lameira, JB Araujo de Almeida, V Isaac \& U Saint-Paul. 2006. Weight-length relationships for intertidal fauna in a mangrove estuary in Northern Brazil. Journal of Applied Ichthyology 22: 325327.

Haimovici M, AS Martins \& PC Vieira. 1996. Distribuição e abundância de peixes teleósteos demersais sobre a plataforma continental do sul do Brasil. Revista Brasileira de Biologia 56: 27-50.

IBAMA. 2008. Monitoramento da atividade pesqueira no litoral nordestino-projeto ESTATPESCA, 385 pp. Convênio SEAP/ IBAMA/PROZEE, Centro de Pesquisa e Gestão de Recursos Pesqueiros do Litoral Nordeste, CEPENE, Tamandaré.

Ikeda RGP. 2003. Idade, crescimento e aspectos reprodutivos de Macrodon ancylodon (Bloch \& Schneider, 1801) na Costa Norte do Brasil). Dissertação Mestrado, Universidade de São Paulo, São Paulo, 112 pp.

Ikeda R, R Souza, L Souza, BB Silva, A Fonseca, C Brito, I Furtado-Júnior, I Pimentel, MF Torres, ACL Castro \& FL Frédou. 2003. Dinâmica populacional da pescada gó Macrodon ancylodon a costa norte do Brasil. Relatório de Atividades, Programa REVIZEE, Brasilia. <http:// www.mma.gov.br/biodiversidade/biodiversidade-aquatica/ zona-costeira-e-marinha/programa-revizee> 
Isaac VJ \& YM Braga. 1999. Rejeição de pescado nas pescarias da região norte do Brasil. Arquivos de Ciências do Mar 32: 39-54.

Isaac-Nahum VJ \& AE de M Vazzoler. 1983. Biologia reprodutiva de Micropogonias furnieri (Desmarest, 1823) (Teleosrei, Sciaenidae), 1. Fator de condicao como indicador do periodo de desova. Boletim do Instituto Oceanográfico 32: 63-69.

Kruskal WH \& WA Wallis. 1952. Use of ranks in one-criterion analysis of variance. Journal of the American Statistical Association 47: 583-621.

Le Cren ED. 1951. The length-weight relationship and seasonal cycle in gonad weight and condition in the perch (Perca fluviatilis). Journal of Animal Ecology 20: 201- 219.

Lowe-Mcconnell RH. 1987. Estudos ecológicos de comunidades de peixes tropicais, 535 pp. Edusp, São Paulo.

Juras AA \& N Yamaguti. 1985. Food and feeding habits of King weakfish, Macrodon ancylodon (Bloch \& Schneider, 1801 ) caught in the southern coast of Brazil (Lat. $29^{\circ}$ to $32^{\circ} \mathrm{S}$ ). Boletim do Instituto Oceanográfico 33: 149-157.

Juras AA \& N Yamaguti. 1989. Sexual maturity, spawning and fecundity of king weakfish Macrodon ancylodon, caught off Rio Grande do Sul State (southern coast of Brazil .Boletim do Instituto Oceanográfico 37: 51-58.

Militelli MI \& GJ Macchi. 2004. Spawning and fecundity of king weakfish, Macrodon ancylodon, in the Río de la Plata estuary, Argentina-Uruguay. Journal of the Marine Biological Association of the United Kingdom 84(2): 443-447.

Militelli MI, GJ Macchi \& K Rodrigues. 2013. Comparative reproductive biology of Sciaenidae family species in the Río de La Plata and Buenos Aires Coastal Zone, Argentina. Journal of the Marine Biological Association of the United Kingdom 93(2): 413-423.

Mourão KRM, FL Frédou, RV Espírito Santo, AM Silva, T Frédou \& V Isaac. 2009. Sistema de produção pesqueira pescada amarela-Cynoscion acoupa Lacèpede (1802): um estudo de caso no litoral nordeste do Pará-Brasil. Boletim do Instituto de Pesca 35: 497-511.

Nikolsky GV. 1963. The ecology of fishes, 352 pp. Academic Press, London.

Ricker WE. 1975. Computation and interpretation of biological statistics of fish populations. Journal of the Fisheries Research Board of Canada 191: 1-382.
Santana JV. 1998. Aspecto da pesca e da biologia da pescada go, Macrodon ancylodon (Bloch \& Schneider, 1801) da costa norte do Brasil. Dissertação de Mestrado, Universidade Federal do Ceará, Fortaleza, 106 pp.

Santos NB. 2007. Biologia reprodutiva de peixes cianídeos capturados nas proximidades dos terminais portuários do Pará e Maranhão. Dissertação de Mestrado, Universidade Federal do Pará, Belém, 86 pp.

Santos SBAF, AC Silva \& MSR Viana. 2003. Aspectos reprodutivos da pescada-do-piauí, Plagioscion squamosissimus (Heckel, 1840), capturada no Açude Pereira Miranda (Pentecoste - Ceará). Revista Ciência Agronômica 34: 5-10.

Santos S, T Hrbek, IP Farias, H Schneider \& I Sampaio. 2006. Population genetic structuring of the king weakfish, Macrodon ancylodon (Sciaenidae), in Atlantic coastal waters of South America: deep genetic divergence without morphological change. Molecular Ecology 15(14): 43614373.

Serpa SS de. 2004. Análise comparativa da pesca de curralem dois municípios da Ilha de São Luís. Monografia de Graduação, Universidade CEUMA, São Luís, 45 pp.

Snedecor GW \& EG Cochram. 1980. Statistical methods, 364 pp. Iowa State University Press, Iowa.

Sokal RR \& FJ Rohlf. 1987. Introduction to biostatistics, 887 pp. Freeman Publication, New York.

Vazzoler AEA de M. 1963. Sobre a fecundidade e a desova da pescada-foguete. Boletim do Instituto Oceanográfico 13: $33-40$.

Vazzoler AEA de M. 1996. Biologia da reprodução dos teleósteos: teoria e prática, 96 pp. SBI/EDUEM, São Paulo.

Vizziano D \& N Berois. 1990. Historia de ovario de Macrodon acylodon (Bloch y Schneider, 1801) (Telostei: Scianediae). Ovogénesis. Foliculos. Revista Brasileña de Biología 50(2): 523-536.

Yamaguti N. 1967. Desova da pescada-foguete, Macrodon ancylodon. Boletim do Instituto Oceanográfico, São Paulo 16: 101-106.

Zar JH. 1996. Biostatistical analysis, 718 pp. Prentice-Hall, Upper Saddler River. 